Yulia Sepreninova,

Ph.D., Associate Professor, Sumy State University, Ukraine

D ORCID ID, 0000-0002-4448-3484

email: y.serpenynova@uabs.sumdu.edu.ua

Inna Makarenko,

Dr.Sc., Associate Professor, Sumy State University, Ukraine

iD ORCID ID,/0000-0001-7326-5374

email: i.makarenko@uabs.sumdu.edu.ua

Alex Plastun,

Dr.Sc., Professor, Sumy State University, Ukraine

(iD) ORCID ID, 0000-0001-8208-7135

email: o.plastun@uabs.sumdu.edu.ua

Angela Babko,

National Health Service of Ukraine,

email: ab_sumuk@yahoo.com

Gunnay Gasimova,

Lecturer, Khazar University, Azerbaijan

email: gunaygasimova@gmail.com

Correspondence author: y.serpenynova@uabs.sumdu.edu.ua

\title{
MAPPING OF THE RESPONSIBLE INVESTMENTS INSTRUMENTS IN SDG 3 "GOOD HEALTH AND WELL-BEING" FINANCING: EU AND US EXPERIENCE
}

Abstract. This article summarizes the existing approaches to investigating instruments of responsible investments in the health care system in Europe and in United States. The main research's purpose is to identify existing instruments of responsible investment under funding Sustainable Development Goal 3: "Good health and well-being". Systematization of scientific sources and approaches on the investigated issue showed no unique approach to forming a list of responsible investment instruments to finance health and well-being in Europe and United States. Hence, existing approaches vary by risk, return, suitability for financing, and so on. Therefore, the analysis and generalization of existing approaches and investigating their implementation-related practical features are the relevant scientific problem. The research's object is the health care financing approaches of the generally recognized organizations such as the Financial Initiative for Biodiversity under the United Nations Development Program, the United States Agency for International Development and the World Bank (Biodiversity Finance Initiative United Nation Development Program, USAID, World Bank). The authors noted that these organizations contributed greatly to provide funding for these projects at the global level. For gaining the research's goal, this study was conducted in the following logical sequence. Firstly, the authors characterized the Biofin financial decisions in health care under the United Nations Development Program. Secondly, the study systematized the U.S. Agency for International Development financing approaches regarding the Sustainable Development Goal 3. Then, the authors generalized the practical directions towards realizing the mentioned above instruments while digging into the World Bank responsible investment activity regarding health care. The study suggested the typology method to identify the key criteria for classifying responsible investment instruments. In turn, the mapping method was used to generalize the scientific background concerning health care finance. Therefore, the findings could help scientists further develop and unify the classification of responsible investment instruments regarding sustainable development and health care financing based on EU and US experience. Moreover, the obtained results enrich the existing global approaches in funding the national health care system and reaching the established Sustainable Development Goals 3 "Good health and wellbeing".

Keywords: health care, financing, investing, bonds, sustainable development.

Cite as: Serpeninova, Yu., Makarenko, I., Plastun, A., Babko, A., \& Gasimova, G. (2020). Mapping of the Responsible Investments Instruments in SDG 3 «Good Health and Well-Being» Financing: EU and US experience. Health Economics and Management Review, 1, 106-115. 
Yu., Serpeninova, I., Makarenko, A., Plastun, A., Babko, G. Gasimova. Mapping of the Responsible Investments Instruments in SDG 3 «Good Health and Well-Being» Financing: EU and US experience

Introduction. Health care finance is a priority for each country. Notably, UNDP HIV, Health and Development Strategy 2016-2021 defines human health as a catalyst and a result of sustainable development (UNDP, 2016). Sustainable Development Goal 3: «Good health and well-being» targeting disease prevention and healthy lifestyle promotion is the global benchmark in health care progress. It stands to mention that SDG 3 is meant to increase financing to health care by 2030 significantly. Besides, it focuses on the recruitment, development, training, and retention of health professionals in developing countries, especially in the least developed countries and small island developing states. The statistical data analysis showed that the annual investment gap by SDG 3 funding for low- and middle-income countries exceeds 371 billion USD (Fullman et al., 2017). Furthermore, this gap significantly deepens under the deployment of the COVID-19 pandemic.

Therefore, the mentioned above raises questions about the possibility of timely implement SDG 3 targets and tasks. Notably, the world community, scientists, regulators, and investment managers had developed a wide range of investment instruments aimed at financing health care to the pandemic occurrence. Thus, there were presented catalytic funding initiatives, socially responsible investing development impact bonds, impact investing, SDG index-linked bonds etc. (Chakravarthy, 2020). However, these instruments have different parameters of risk, return, suitability for financing under SDG3. Therefore, it is appropriate to classify them.

Literature Review. Systematization of scientific background devoted to SDG 3 investment instruments indicated the scientific interest growth on these issues. Thus, many publications in this area aimed to analyze global health care financing (Fullman et al., 2017; Dieleman et al., 2018; Stenberg et al., 2017).

In turn, Fullman et al. (2017) involved data on health care financing in 188 countries from 1995 to 2015 to perform a baseline assessment of 37 out of 50 SDG indicators in health care. The researchers provided the calculation of the health care expenditures until 2030. Therefore, the findings allowed the authors to conclude that low- and middle-income countries would face a challenge to reach SDG 3 by 2030 due to limited funding and several other factors until 2030.

It stands to mention that several scientists hold the same opinion. In turn, Dieleman et al. (2018) analyzed financial data in health care for 1995-2015 to forecast the health care expenditures until 2040 based on a scenario approach. The predictions indicated the notable variation in further health care expenditures per capita. The authors concluded that until 2040 , the high-income countries would increase the total health care expenditures per capita by 45 times compared to the low-income countries.

Stenberg et al. (2017) investigated 67 low- and middle-income countries to assess the adequacy of the resources needed nationally and globally to achieve healthcare-related SDGs.

Dodd et al. (2020) emphasized the significant misunderstanding in the needed funding to cover all SDG health care targets. Dieleman et al. (2018) noted that providing universal healthcare coverage requires an effective pooled resources system to fund key healthcare services. In turn, the list of these resources includes government spending (prepaid revenues through government financing and social health insurance), prepaid private spending (through private insurance), out-of-pocket spending, development assistance for health. It is worth mentioning that, in the aggregate, they mitigate the excessive financial stress for households.

Herewith, it is necessary to consider the financing SDG 3 issued under the fiscal instruments. Thus, Savedoff (World Health Organization, 2004) analyzed the experience and approaches for implementing tax-based financing for health systems. In the study (Sugar et al., 2018) the researchers examined excise taxes on tobacco, alcohol, and sugar in SDG 3 financing.

Consequently, identification of typical instruments for health care responsible investment is the key to their effective use. Alongside that, it allows providing the resource sufficiency to finance the SDG 3 targets by 2030 . However, the construction of integrated mapping and typology investment instruments approach aimed at financing SDG 3 remains insufficiently covered in academic circles. 
Yu., Serpeninova, l., Makarenko, A., Plastun, A., Babko, G., Gasimova. Mapping of the Responsible Investments Instruments in SDG 3 «Good Health and Well-Being» Financing: EU and US experience

Methodology and research methods. This study's practical part involved the typology method to identify the key criteria for classifying responsible investment instruments. Besides, the study implemented the mapping method to generalize the scientific background in healthcare finance. These methods allowed analyzing approaches to identify the responsible investment instruments of investigated organizations. The research's objects were the Biodiversity Finance Initiative, the United Nations Development Program, and USAID, which are known for their sustainable development initiatives and financing.

Results. The Biodiversity Finance Initiative developed the significant aspects of SDG financing development (UNDP, 2018). Notably, nowadays, more than 30 countries effectively use the above methodology.

It is appropriate to mention that the BIOFIN Process (UNDP, 2018) aims to identify priority actions and instruments for their funding to provide positive changes in current society. Most of the determined by the BIOFIN process actions are carried out through «financial decisions». Herewith, the financial decision is an integrated approach to solve a particular problem or challenge under a specific direction providing economic instruments. It is based on various elements that include financial instruments, funding sources, performers, beneficiaries (key stakeholders) and the expected financial result.

It is worth mentioning that regulatory, marketing, fiscal, grant, equity/debt and risk instruments are the universal financing instruments for SDGs (particularly SDG 3) that could be considered responsible. Herewith, these instruments aim to generate income, achieve higher results, redistribute or avoid future costs while transferring investment resources into sustainable development projects (UNDP, 2018).

Table 1 provides general information on the recommended funding sources for SDG 3. There are examples of their implementation within the world experience according to the UNDP methodology. The listed below solutions offer a wide range of funding options to increase resource efficiency to reach SDG 3. However, that is not an exhaustive list of financing options for health and well-being improvement.

Table 1. SDG 3 funding instruments according to UNDP approaches

\begin{tabular}{|c|c|c|c|}
\hline 1 & Title & Description & Implementation examples \\
\hline 1 & Bioprospecting & $\begin{array}{l}\text { Systematic searching for biochemical and } \\
\text { genetic information in nature for further } \\
\text { developing commercially valuable products and } \\
\text { programs. }\end{array}$ & $\begin{array}{l}\text { - the Nagoya Protocol Implementation Fund } \\
\text { in Bhutan; } \\
\text { - stimulating investment in African bio- } \\
\text { economies }\end{array}$ \\
\hline 2 & $\begin{array}{l}\text { Impact } \\
\text { investment }\end{array}$ & $\begin{array}{l}\text { Investing in getting a specific social and } \\
\text { environmental influence concerning financial } \\
\text { feasibility. }\end{array}$ & $\begin{array}{l}\text { - SDG-Impact Standards; } \\
\text { - SDG-Impact Finance in Asia. }\end{array}$ \\
\hline 3 & $\begin{array}{l}\text { Remittances } \\
\text { (Diaspora } \\
\text { Financing) }\end{array}$ & $\begin{array}{l}\text { Private uncompensated transfers sent from } \\
\text { abroad to families and communities in the } \\
\text { payer's country of origin. }\end{array}$ & $\begin{array}{l}\text { Kazakhstan and Kyrgyzstan are the leaders in } \\
\text { this direction. }\end{array}$ \\
\hline 4 & $\begin{array}{l}\text { Taxes on } \\
\text { pesticides and } \\
\text { chemical } \\
\text { fertilizers }\end{array}$ & $\begin{array}{l}\text { The imposition of taxes levied on } \\
\text { pesticides and chemical fertilizers could mobilize } \\
\text { fiscal revenues while mitigating the adverse } \\
\text { outcomes due to their use. }\end{array}$ & $\begin{array}{l}\text { USA experience. } \\
\text { Pesticide tax revenues are fully accumulated in } \\
\text { the Department of Ecology in the State of } \\
\text { Washington (OECD). Then, they are directed to } \\
\text { specific purposes (support for organic } \\
\text { production, research funding, etc.). }\end{array}$ \\
\hline 5 & Crowdfunding & $\begin{array}{l}\text { Attracting several individual donors or investors } \\
\text { to finance funds to finance projects, } \\
\text { organizations, entrepreneurs and startups. }\end{array}$ & $\begin{array}{l}\text { - The United Nations Development Programme } \\
\text { (UNDP) and impact investment platform TRINE } \\
\text { partnership for the solar industry in Sub-Saharan } \\
\text { Africa; } \\
\text { - Project Live Lebanon. }\end{array}$ \\
\hline 6 & Lotteries & $\begin{array}{l}\text { Lotteries could be used by the government and } \\
\text { civil society charity fundraising, such as health } \\
\text { care. }\end{array}$ & $\begin{array}{l}\text { The national lotteries could direct part of the } \\
\text { funds to special funds, including those financing } \\
\text { health care needs (for example, the Heritage } \\
\text { Lottery Fund (UK), Oregon Lottery (USA)). }\end{array}$ \\
\hline
\end{tabular}


Yu., Serpeninova, I., Makarenko, A., Plastun, A., Babko, G. Gasimova. Mapping of the Responsible Investments Instruments in SDG 3 «Good Health and Well-Being» Financing: EU and US experience

\begin{tabular}{|c|c|c|c|}
\hline & & & Continued Table 1 \\
\hline 7 & $\begin{array}{l}\text { Social and } \\
\text { development } \\
\text { impact bonds } \\
\text { (Results-Based } \\
\text { Financing) }\end{array}$ & $\begin{array}{l}\text { The public-private partnership aims to ensure } \\
\text { capital investment by private investors in public } \\
\text { projects providing social and environmental } \\
\text { results under financial interest. }\end{array}$ & $\begin{array}{l}\text { On-going initiatives in Africa for health purposes, } \\
\text { for example, One-Health Financing Pilot, } \\
\text { Transitioning from Tobacco. }\end{array}$ \\
\hline 8 & $\begin{array}{l}\text { Taxes on } \\
\text { tobacco }\end{array}$ & $\begin{array}{l}\text { Excise taxes on tobacco products provide fiscal } \\
\text { revenues growth while improving health and } \\
\text { well-being. }\end{array}$ & $\begin{array}{l}\text { The extensive experience in financing SDG } 3 \\
\text { through excise taxes on tobacco and alcohol } \\
\text { products. Besides, there are also examples of } \\
\text { excise taxes on sugar (Mexico's sugar tax). }\end{array}$ \\
\hline 9 & $\begin{array}{l}\text { Environmental } \\
\text { trust funds }\end{array}$ & $\begin{array}{l}\text { Funds providing an investment vehicle for } \\
\text { mobilizing, using and controlling fundraising and } \\
\text { financial resources distribution for environmental } \\
\text { goals. }\end{array}$ & $\begin{array}{l}\text { Environmental trust funds allow using the } \\
\text { existing fundraising mechanisms to fund health } \\
\text { care. For example, the Bhutan Trust Fund for } \\
\text { Environmental Conservation supports the } \\
\text { remedial action in the wake of Covid-19. }\end{array}$ \\
\hline 10 & $\begin{array}{l}\text { Payments for } \\
\text { ecosystem } \\
\text { services }\end{array}$ & $\begin{array}{l}\text { Payments for environmental services when an } \\
\text { environmental service user (beneficiary) effects } \\
\text { a direct or indirect payment to a service provider }\end{array}$ & $\begin{array}{l}\text { The Biodiversity Finance Initiative (BIOFIN } \\
\text { workbook, 2018) methodology used in } 35 \\
\text { countries nowadays. }\end{array}$ \\
\hline 11 & Taxes on fuel & $\begin{array}{l}\text { Fuel taxes provide fiscal revenues while reducing } \\
\text { fuel consumption and greenhouse gas } \\
\text { emissions. }\end{array}$ & $\begin{array}{l}\text { Fiscal instruments allow using the existing } \\
\text { mobilizing fund mechanisms to finance health } \\
\text { care - for example, the Fuel Tax Refund } \\
\text { program for people with disabilities in British } \\
\text { Columbia. }\end{array}$ \\
\hline 12 & $\begin{array}{l}\text { Voluntary } \\
\text { standards } \\
\text { (finance) }\end{array}$ & $\begin{array}{l}\text { The financial sector standards covering the best } \\
\text { practices and encourage environmental and } \\
\text { social performance achievement and monitoring. }\end{array}$ & $\begin{array}{l}\text { Business Call to Action (BCtA) } \\
\text { Business Call to Action (BCtA) initiative aiming } \\
\text { to accelerate progress towards the SDG } \\
\text { implementation. }\end{array}$ \\
\hline
\end{tabular}

A key feature of the responsible investment typology is making a profit during its use. Thus, the investment instrument should compensate invested funds, show the leverage effect, and be profitable. In turn, Chakravarthy (2020) classified all investment instruments in SDG 3 by several groups as follows:

- New taxation channel (capital conversion);

- Result based financing (no investment refunding);

- $\quad$ Catalytic funding (lossless instruments);

- Impact investing (reimbursement and additional profitability);

- $\quad$ Socially responsible investment (reimbursement and additional profitability).

The approach mentioned above is based on the classification of financial instruments in USAID SDG 3. Table 2 shows 8 classified investment instrument groups aimed at achieving progress in financing SDG 3.

Table 2. Approaches to financing global health according to USAID

\begin{tabular}{|c|c|c|c|c|}
\hline Financing tools & Characteristic & Necessity and Impact & $\begin{array}{l}\text { Mechanism of } \\
\text { implementation }\end{array}$ & Instruments \\
\hline Guarantee & $\begin{array}{l}\text { Protecting creditors who } \\
\text { want to invest in } \\
\text { essential but risky and } \\
\text { not consistently } \\
\text { profitable fields, such as } \\
\text { healthcare }\end{array}$ & $\begin{array}{l}\text { Mobilizing private } \\
\text { investors' funds to } \\
\text { increase cash inflows } \\
\text { to health care } \\
\text { providers }\end{array}$ & $\begin{array}{l}\text { The guarantor covers } \\
\text { a predetermined } \\
\text { amount of creditors' } \\
\text { investment in case of } \\
\text { failure }\end{array}$ & $\begin{array}{l}\text { A wide range of } \\
\text { instruments from loan } \\
\text { repayment to } \\
\text { investment losses }\end{array}$ \\
\hline
\end{tabular}


Yu., Serpeninova, l., Makarenko, A., Plastun, A., Babko, G., Gasimova. Mapping of the Responsible Investments Instruments in SDG 3 «Good Health and Well-Being» Financing: EU and US experience

\begin{tabular}{|c|c|c|c|c|}
\hline & & & & Continued Table 2 \\
\hline Debt swap & $\begin{array}{l}\text { Relieving the debt } \\
\text { burden of developing } \\
\text { countries and providing } \\
\text { resources for vital health } \\
\text { care projects }\end{array}$ & $\begin{array}{l}\text { Assisting governments } \\
\text { with limited budgets in } \\
\text { meeting their } \\
\text { commitments under } \\
\text { sustainable } \\
\text { development in health } \\
\text { care }\end{array}$ & $\begin{array}{l}\text { Creditors (private } \\
\text { investors, } \\
\text { governments, etc.) } \\
\text { release part of the } \\
\text { country's debt }\end{array}$ & $\begin{array}{l}\text { Charge-off of debts of } \\
\text { developing countries } \\
\text { or transfer of these } \\
\text { debts to other } \\
\text { organizations subject } \\
\text { to the targeted use of } \\
\text { these resources }\end{array}$ \\
\hline $\begin{array}{l}\text { Pooled } \\
\text { investment funds }\end{array}$ & $\begin{array}{l}\text { Funds from several } \\
\text { parties are aggregated } \\
\text { and used to support } \\
\text { specific social changes }\end{array}$ & $\begin{array}{l}\text { Promoting the private } \\
\text { health care sector } \\
\text { development }\end{array}$ & $\begin{array}{l}\text { Private investors work } \\
\text { with public or private } \\
\text { donors to pool funds } \\
\text { for investing in the } \\
\text { business or other } \\
\text { funds }\end{array}$ & $\begin{array}{l}\text { Combining individual } \\
\text { capital with donor } \\
\text { funding and providing } \\
\text { technical assistance to } \\
\text { all investment project's } \\
\text { parties }\end{array}$ \\
\hline Social insurance & $\begin{array}{l}\text { Social insurance could } \\
\text { protect against possible } \\
\text { loss or non-return }\end{array}$ & $\begin{array}{l}\text { Expanding private- } \\
\text { sector resources by } \\
\text { reducing risk and } \\
\text { encouraging } \\
\text { engagement with } \\
\text { development actors }\end{array}$ & $\begin{array}{l}\text { The risk coverage by } \\
\text { the triparty agent }\end{array}$ & Insurance instruments \\
\hline $\begin{array}{l}\text { Seed funding / } \\
\text { flexible grand } \\
\text { capital }\end{array}$ & $\begin{array}{l}\text { Financing that is similar } \\
\text { to venture capital aimed } \\
\text { to finance high-risk } \\
\text { technologies that could } \\
\text { commercialize or scale } \\
\text { other projects }\end{array}$ & $\begin{array}{l}\text { Promoting the private } \\
\text { health care sector } \\
\text { development }\end{array}$ & $\begin{array}{l}\text { Donor application of a } \\
\text { venture approach to } \\
\text { financing }\end{array}$ & $\begin{array}{l}\text { Venture investment } \\
\text { tools }\end{array}$ \\
\hline $\begin{array}{l}\text { Milestone-based } \\
\text { payments }\end{array}$ & $\begin{array}{l}\text { The funding paid to } \\
\text { recipients after getting } \\
\text { the predetermined } \\
\text { results or indicators }\end{array}$ & $\begin{array}{l}\text { Stimulating the } \\
\text { achievement of } \\
\text { established targets }\end{array}$ & $\begin{array}{l}\text { Focusing on achieving } \\
\text { specific indicators }\end{array}$ & $\begin{array}{l}\text { Traditional investment } \\
\text { channels with } \\
\text { strengthening } \\
\text { reporting systems }\end{array}$ \\
\hline $\begin{array}{l}\text { Development } \\
\text { income bonds }\end{array}$ & $\begin{array}{l}\text { Financing model } \\
\text { providing payment after } \\
\text { getting a predetermined } \\
\text { social result (specific } \\
\text { results for investors, } \\
\text { service providers and } \\
\text { independent evaluation) }\end{array}$ & $\begin{array}{l}\text { Improving the } \\
\text { efficiency of public } \\
\text { spending by ensuring } \\
\text { the achievement of the } \\
\text { planned results } \\
\text { through investing in } \\
\text { programs }\end{array}$ & $\begin{array}{l}\text { Financing the pre- } \\
\text { agreed results upon } \\
\text { their achievement }\end{array}$ & $\begin{array}{l}\text { Pay-for-success } \\
\text { agreements }\end{array}$ \\
\hline $\begin{array}{l}\text { Co-funding / } \\
\text { Global } \\
\text { Development } \\
\text { Alliance } \\
\text { agreements }\end{array}$ & $\begin{array}{l}\text { It brings additional } \\
\text { resources and new } \\
\text { knowledge that allows } \\
\text { implementation of } \\
\text { different health care } \\
\text { programs }\end{array}$ & $\begin{array}{l}\text { Mobilizing private } \\
\text { sector capital for } \\
\text { global health care } \\
\text { programs }\end{array}$ & $\begin{array}{l}\text { Attracting external } \\
\text { funding for key } \\
\text { investments in health } \\
\text { care through technical } \\
\text { assistance and } \\
\text { targeting financing }\end{array}$ & $\begin{array}{l}\text { Co-created, co- } \\
\text { developed, and co- } \\
\text { implemented } \\
\text { agreements and entail } \\
\text { extensive partnering } \\
\text { and collaboration } \\
\text { between USAID and } \\
\text { the private sector }\end{array}$ \\
\hline
\end{tabular}

Sources: developed by the authors.

It stands to note that the practical implementation of considered approaches is possible as in highincome countries (guarantee), so in low-income countries (debt swap). Besides, they could be implemented without dependence on the health care system development in a particular country (pooled investment funds, social insurance, impact investment). 
Yu., Serpeninova, I., Makarenko, A., Plastun, A., Babko, G. Gasimova. Mapping of the Responsible Investments Instruments in SDG 3 «Good Health and Well-Being» Financing: EU and US experience

\begin{tabular}{|c|c|c|c|c|}
\hline Financing tools & $\begin{array}{l}\text { Conditions for } \\
\text { providers of } \\
\text { finance }\end{array}$ & $\begin{array}{l}\text { Conditions for recipients } \\
\text { of finance }\end{array}$ & $\begin{array}{l}\text { Implementation by } \\
\text { USAID mission } \\
\text { officers }\end{array}$ & Practical Example \\
\hline Guarantee & $\begin{array}{l}\text { Striving to repay loan } \\
\text { portfolios on a } \\
\text { market basis with } \\
\text { relatively low-risk } \\
\text { tolerance }\end{array}$ & $\begin{array}{l}\text { Operates in a country with } \\
\text { enough developed } \\
\text { financial market (existing } \\
\text { active loan market, } \\
\text { established repayment } \\
\text { mechanisms), but there is } \\
\text { no quality credit history to } \\
\text { get the loan }\end{array}$ & $\begin{array}{l}\text { Provide structure } \\
\text { guarantees through } \\
\text { the Development } \\
\text { Credit Authority } \\
\text { (DCA) }\end{array}$ & $\begin{array}{l}\text { DCA has an } \\
\text { agreement with the } \\
\text { USAID Uganda } \\
\text { Mission and Sida to } \\
\text { provide } 3 \text { million USD } \\
\text { loan portfolio } \\
\text { guarantee for } 7 \text { years } \\
\text { to provide access to } \\
\text { investments for the } \\
\text { Ugandan private } \\
\text { health sector }\end{array}$ \\
\hline Debt swap & $\begin{array}{l}\text { Holding the country's } \\
\text { debt and remaining } \\
\text { willing to sell or } \\
\text { release a deb on } \\
\text { condition of social } \\
\text { impact }\end{array}$ & $\begin{array}{l}\text { The opportunity to } \\
\text { administer funds for social } \\
\text { programs, but there is a } \\
\text { high level of debt and lack } \\
\text { of public resources for } \\
\text { development programs }\end{array}$ & $\begin{array}{l}\text { Analyze appropriate } \\
\text { circumstances for a } \\
\text { debt swap in } \\
\text { cooperation with } \\
\text { USAID technical } \\
\text { experts who facilitate } \\
\text { the arrangement }\end{array}$ & $\begin{array}{l}\text { «Debt for Nature» as a } \\
\text { result of The Tropical } \\
\text { Forest Conservation } \\
\text { Act (1998) }\end{array}$ \\
\hline $\begin{array}{l}\text { Pooled } \\
\text { investment funds }\end{array}$ & $\begin{array}{l}\text { Interested in } \\
\text { investing in the } \\
\text { health care sector, } \\
\text { but need to } \\
\text { understand the } \\
\text { mechanisms for } \\
\text { achieving the desired } \\
\text { risk/return ratio or } \\
\text { technical support of } \\
\text { their investment }\end{array}$ & $\begin{array}{l}\text { Financially viable and } \\
\text { attractive private-sector } \\
\text { medical business models, } \\
\text { but there is a need for } \\
\text { investment capital to scale } \\
\text { the maximizing impact }\end{array}$ & $\begin{array}{l}\text { Provide grants or } \\
\text { guarantees (or other } \\
\text { concessional capital) } \\
\text { to investment funds. } \\
\text { Provide technical } \\
\text { assistance to } \\
\text { investment funds }\end{array}$ & $\begin{array}{l}\text { USAID provides strong } \\
\text { support to the Global } \\
\text { Innovation Fund (GIF): } \\
£ 50,000-5 \text { million } \\
\text { (grants, loans, } \\
\text { equity/debt } \\
\text { investments etc.) } \\
\text { Convergence, global } \\
\text { partnerships } \\
\text { investment Funds, } \\
\text { (2017) } \\
\text { Global Innovation } \\
\text { Fund (2016) }\end{array}$ \\
\hline Social insurance & $\begin{array}{l}\text { Interested in } \\
\text { investing in social } \\
\text { impact projects, but } \\
\text { they could need } \\
\text { some protection } \\
\text { against the risk of } \\
\text { losing their } \\
\text { investment }\end{array}$ & $\begin{array}{l}\text { Financially viable and } \\
\text { attractive private-sector } \\
\text { medical business models, } \\
\text { but there is a need for } \\
\text { investment capital to scale } \\
\text { the maximizing impact }\end{array}$ & $\begin{array}{l}\text { Identify appropriate } \\
\text { circumstances for } \\
\text { social insurance in } \\
\text { cooperation with } \\
\text { USAID technical } \\
\text { experts who facilitate } \\
\text { the arrangement }\end{array}$ & $\begin{array}{l}\text { USAID partnership } \\
\text { with Aspen } \\
\text { Pharmacare, Imperial } \\
\text { Health Sciences, } \\
\text { Pfizer, etc. to create } \\
\text { Lulama (an innovative } \\
\text { financing model that } \\
\text { provides pharmacies in } \\
\text { South Africa) }\end{array}$ \\
\hline $\begin{array}{l}\text { Seed funding / } \\
\text { flexible grand } \\
\text { capital }\end{array}$ & $\begin{array}{l}\text { Need in the proven } \\
\text { or commercially } \\
\text { viable model before } \\
\text { they invest in scaling } \\
\text { up }\end{array}$ & $\begin{array}{l}\text { High potential ideas and } \\
\text { need to demonstrate the } \\
\text { evidence of the concept of } \\
\text { significant impact on health } \\
\text { care and the path to } \\
\text { sustainable scale }\end{array}$ & $\begin{array}{l}\text { Use the Grand } \\
\text { Challenges for } \\
\text { Development (GCD) } \\
\text { mechanism or } \\
\text { Development } \\
\text { Innovation ventures } \\
\text { (DIv) mechanism to } \\
\text { identify social } \\
\text { enterprises or } \\
\text { innovators for seed } \\
\text { funding }\end{array}$ & $\begin{array}{l}\text { Saving Lives at Birth } \\
\text { (USAID has } \\
\text { contributed } 20 \text { million } \\
\text { USD), Grand } \\
\text { Challenge for } \\
\text { Development (which } \\
\text { leveraged } 80 \text { million } \\
\text { USD in donor funds) } \\
\text { providing seed funding } \\
\text { for new approaches to } \\
\text { addressing maternal } \\
\text { and neonatal mortality }\end{array}$ \\
\hline
\end{tabular}


Yu., Serpeninova, l., Makarenko, A., Plastun, A., Babko, G., Gasimova. Mapping of the Responsible Investments Instruments in SDG 3 «Good Health and Well-Being» Financing: EU and US experience

\begin{tabular}{|c|c|c|c|c|}
\hline & & & & Continued Table 3 \\
\hline $\begin{array}{l}\text { Milestone-based } \\
\text { payments }\end{array}$ & $\begin{array}{l}\text { Readiness to take } \\
\text { risks (limited budget, } \\
\text { political pressure to } \\
\text { implement) under the } \\
\text { additional need for } \\
\text { further stimulating } \\
\text { the implementation } \\
\text { of the effective } \\
\text { project by } \\
\text { contractors }\end{array}$ & $\begin{array}{l}\text { Possibility to cover the } \\
\text { project costs to the } \\
\text { expected disbursements } \\
\text { and reliably and carefully } \\
\text { assess the planned results }\end{array}$ & $\begin{array}{l}\text { Identify appropriate } \\
\text { programs and } \\
\text { partners for } \\
\text { milestone-based } \\
\text { payments and utilize } \\
\text { USAID technical and } \\
\text { support to negotiate } \\
\text { the terms with } \\
\text { partners }\end{array}$ & $\begin{array}{l}\text { Part of the Global } \\
\text { Development Lab. } \\
\text { Development } \\
\text { Innovation ventures } \\
\text { (DIV) provides staged } \\
\text { financing for chosen } \\
\text { projects }\end{array}$ \\
\hline $\begin{array}{l}\text { Development } \\
\text { income bonds }\end{array}$ & $\begin{array}{l}\text { Capability to clearly } \\
\text { define development } \\
\text { outcomes by the } \\
\text { criteria as follows: } \\
\text { significant, } \\
\text { measurable, } \\
\text { intervention-related } \\
\text { and quantifiable in } \\
\text { terms of costs and } \\
\text { social benefits }\end{array}$ & $\begin{array}{l}\text { Using rigorous evaluation } \\
\text { methods to measure the } \\
\text { impact of their } \\
\text { interventions while } \\
\text { empowered to introduce } \\
\text { innovations and apply a } \\
\text { results-oriented approach }\end{array}$ & $\begin{array}{l}\text { Identify programs for } \\
\text { impact bond funding } \\
\text { and work with USAID } \\
\text { technical experts to } \\
\text { facilitate agreements. }\end{array}$ & $\begin{array}{l}\text { Apay-for-success } \\
\text { agreement by } \\
\text { improving the quality of } \\
\text { maternal and neonatal } \\
\text { care in India }\end{array}$ \\
\hline $\begin{array}{l}\text { Co-funding / } \\
\text { Global } \\
\text { Development } \\
\text { Alliance } \\
\text { agreements }\end{array}$ & $\begin{array}{l}\text { Coordinating the } \\
\text { goals of the public } \\
\text { and private sector }\end{array}$ & $\begin{array}{l}\text { Ability to effectively use } \\
\text { public and private funds } \\
\text { and comply with } \\
\text { requirements of both } \\
\text { parties }\end{array}$ & $\begin{array}{l}\text { Coordinate these } \\
\text { programs }\end{array}$ & $\begin{array}{l}\text { Through the Global } \\
\text { Development Alliance } \\
\text { agreements, USAID } \\
\text { and other donors } \\
\text { cooperated with Coca- } \\
\text { Cola to improve the } \\
\text { supply of essential } \\
\text { medicines in Africa }\end{array}$ \\
\hline
\end{tabular}

Sources: developed by the authors.

Following the Biofin, UNDP, USAID approaches, the considered instruments' systematization indicated the demand and practical value of investment instruments in health care. However, the classical approach implies responsible investing as investments to achieve joint social, environmental, and financial (income maximization, risk minimization) goals. Therefore, not all instruments mentioned above could be interpreted as responsible. In this study, it is proposed to consider generating income (leverage) as a key feature for their classification. Accordingly, the set of investment instruments in SDG 3 responsible investing should include debt (equity) instruments aimed at investment refunding and ensuring its revenue assurance. Thus, under the instruments mentioned above, the following match this criterion:

- $\quad$ under Biofin and UNDP approaches (Impact investment, Crowdfunding, Social and development impact bonds (Results-Based Financing);

- $\quad$ under USAID approach (Pooled investment funds, Development income bonds, Social Bonds).

It is worth noting that the World Bank Group bonds showed success in applying the theoretical concept of debt instruments generating income in responsible investment. In turn, the World Bank Group bonds aimed at financing the targets of CSW 3 fall into 5-year sustainable development bonds and benchmark bonds, which are denominated in Canadian dollars (Table 4). Notably, in January 2019, the sustainable development bonds issues became the largest bond issue in the Sovereign Supranational agency's history in the Canadian market.

Table 4. Parameters of World Bank instruments aimed at SDG 3 financing

\begin{tabular}{cll}
\hline Instrument & 1,5 billion CAD Sustainable development bond & \multicolumn{1}{c}{1 bilion CAD behchmark bond } \\
\hline Goal & Investing in women and young people & $\begin{array}{l}\text { Investing in the health, nutrition of women, children and } \\
\text { adolescents }\end{array}$ \\
\hline
\end{tabular}


Yu., Serpeninova, I., Makarenko, A., Plastun, A., Babko, G. Gasimova. Mapping of the Responsible Investments Instruments in SDG 3 «Good Health and Well-Being» Financing: EU and US experience

\begin{tabular}{lll} 
& \multicolumn{2}{c}{ Continued Table 4} \\
\hline Date & July 2018 & January 2019 \\
\hline Issuer & $\begin{array}{l}\text { World Bank (International Bank for } \\
\text { Reconstruction and Development, IBRD) }\end{array}$ & $\begin{array}{l}\text { World Bank (International Bank for Reconstruction and } \\
\text { Development, IBRD }\end{array}$ \\
\hline Issuer rating & Aaa / AAA & Aaa / AAA \\
\hline Amount & 1 billion CAD & 1.5 billion CAD \\
\hline $\begin{array}{l}\text { Settlement } \\
\text { date }\end{array}$ & August 3, 2018 & January 16, 2020 \\
\hline Maturity date & August 3, 2023 & January 16, 2025 \\
\hline Issue price & $99.613 \%$ & $99.896 \%$ \\
\hline Coupon & $2.50 \%$ per annum & $1.900 \%$ per annum \\
\hline Denomination & 1,000 CAD and multiples thereof & 1,000 CAD x 1,000 CAD \\
\hline Listing & Luxembourg Stock Exchange & Luxembourg Stock Exchange \\
\hline
\end{tabular}

Sources: developed by the authors based on (WBG, 2018; WBG, 2020a).

The World Bank's responsible investment in health care is significant among international financial institutions. Notably, for counteracting the COVID-19 pandemic, the World Bank allocated 160 billion USD. Besides, it is expected to mobilize 50-55 billion USD by June 2021. The World Bank's general program's measures above are provided to strengthen health care systems in developing countries. Table 5 shows the examples of this program implementation in different countries.

Table 5. Investments in the health care systems of developing countries

\begin{tabular}{ccc}
\hline Country & Amount & Focus \\
\hline Argentina & 35 million USD & Strengthening the health care system \\
\hline $\begin{array}{c}\text { Dominican } \\
\text { Republic }\end{array}$ & 150 million USD & Implementing the measures to counter the pandemic spread \\
\hline Ecuador & 20 million USD & Preventive and consolidate measures in the health care system \\
\hline India & U1 billion USD & Purchasing some tools to counter the pandemic \\
\hline Levan & 40 million USD & The healthcare system restructuring in terms of procurement \\
\hline Pakistan & 200 million USD & $\begin{array}{c}\text { Support for preparedness and rapid response in the health care } \\
\text { system, including social support }\end{array}$ \\
\hline
\end{tabular}

Sources: developed by the authors based on (WBG, 2020c).

Furthermore, for financing sustainable development, the World Bank developed and implemented some more investment instruments in addition to the mentioned bonds (Table 6). In turn, they focus on the environmental, social and managerial aspects in SDG targets achievement. Moreover, these instruments allow maximizing certain investment parameters and benefits for investors, combining them with sustainable development values.

Table 6. Classes of World Bank investment instruments aimed at financing SDG

\begin{tabular}{|c|c|c|}
\hline Instrument & Focus & Investors benefits \\
\hline $\begin{array}{l}\text { Global \& Benchmark } \\
\text { Bonds }\end{array}$ & Liquidity & The high quality of IBRD loans provides the benefits of investing. \\
\hline $\begin{array}{l}\text { Non-Core Currency } \\
\text { Bonds }\end{array}$ & Diversification & $\begin{array}{l}\text { Opportunities for diversification of the investment portfolio, including } \\
\text { through entering the markets of developing countries. }\end{array}$ \\
\hline $\begin{array}{l}\text { Structured Notes and } \\
\text { Callable Bonds }\end{array}$ & $\begin{array}{l}\text { Flexible adaptation to } \\
\text { customer needs }\end{array}$ & Special attention to the customers' requests and individual needs. \\
\hline Capital at risk - Notes & $\begin{array}{l}\text { The potential for additional } \\
\text { income }\end{array}$ & $\begin{array}{l}\text { Facilitating the risk transfer of the bank and investors in the capital } \\
\text { markets. }\end{array}$ \\
\hline Discount Notes & Cash management & Short-term investment opportunities in the dollar and euro markets. \\
\hline
\end{tabular}

Sources: developed by the authors based on (2020b). 
Yu., Serpeninova, l., Makarenko, A., Plastun, A., Babko, G., Gasimova. Mapping of the Responsible Investments Instruments in SDG 3 «Good Health and Well-Being» Financing: EU and US experience

Conclusions. The significant variety of financial instruments aimed to finance SDG 3 determines the importance of their typology and mapping.

The approaches generalization to the classification of financial decisions and investment instruments of such reputable organizations as Biofin, UNDP, USAID revealed different financial instruments applicable for health care worldwide. Moreover, the global pandemic spread increased the importance of effective implementation of such tools.

The findings showed that debt (equity) instruments generating income most fully meet the responsible investment criteria. In turn, the debt (equity) instruments aimed at investment refunding and ensuring its revenue assurance for investors are specific to SDG 3. Under the Biofin and UNDP approaches, it is worth highlighting the following: impact investment, crowdfunding, social and development impact bonds (Results-Based Financing), while under the USAID approaches - Pooled investment funds, Development income bonds, Social Bonds).

The successful application of the theoretical concept of debt instruments confirmed the author's conclusions. Therefore, the World Bank Group bonds aimed at financing the targets of the CSB 3 generate the income in the field of responsible investment

Author Contributions: conceptualization, I. M, and Yu. S.; methodology, A. P.; software, A. P., and I. M.; validation, A. B., G. G.; formal analysis, A. B.; investigation, Yu. S.; resources, A. P. and I. M.; writing-original draft preparation, A. P., I. M., and Yu. S.; writing-review and editing, A. P. I. M., and Yu. S.; visualization, I. M.; supervision, A. P., G. G.; project administration, I. M.; funding acquisition, A. P. I. M., and Yu. S.

Acknowledgments: The authors are grateful for the support of the research within the Grant of the Ministry of Education and Science of Ukraine and the Federal Ministry of Science, Research and Economy of the Republic of Austria, the Austrian Agency for International Cooperation in Education and Research to support Ukrainian-Austrian research projects as an element of improving the health care system 15.02/15-01/1617.

Funding: This research was funded by Austrian-Ukrainian bilateral grant and MSE of Ukraine $0121 \mathrm{U} 100473$.

\section{References}

Chakravarthy, M. (2020) Putting the innovation back into innovative financing for health. Retrieved from [Link]

Dieleman, J. L., Sadat, N., Chang, A. Y., Fullman, N., Abbafati, C., Acharya, P., .. \& Murray, C. J. (2018). Trends in future health financing and coverage: future health spending and universal health coverage in 188 countries, 2016-40. The Lancet, 391(10132), 1783-1798. [Google Scholar] [CrossRef]

Dodd, A., Caio, C., \& Meeks, P. (2020). The cost achieving SDG 3 and SDG 4: How complete are financing estimates for the health and education goals? [Link]

Financing Solutions for Sustainable Development. Retrieved from [Link]

Fullman, N., Barber, R. M., Abajobir, A. A., Abate, K. H., Abbafati, C., Abbas, K. M., ... \& Dubey, M. (2017). Measuring progress and projecting attainment on the basis of past trends of the health-related Sustainable Development Goals in 188 countries: an analysis from the Global Burden of Disease Study 2016. The Lancet, 390(10100), 1423-1459. [Google Scholar] [CrossRef]

Sustainable Development Goals in Ukraine. Retrieved from [Link

Stenberg, K., Hanssen, O., Edejer, T. T. T., Bertram, M., Brindley, C., Meshreky, A., ... \& Soucat, A. (2017). Financing transformative health systems towards achievement of the health Sustainable Development Goals: a model for projected resource needs in 67 low-income and middle-income countries. The Lancet Global Health, 5(9), 875-887. [Google Scholar] [CrossRef]

Sugar, T. (2018). Sugar, tobacco, and alcohol taxes to achieve the SDGs. Lancet, 391(10138), 2400-2401. [Google Scholar] CrossRef

UNDP. (2016). HIV, Health and Development Strategy 2016-2021. Retrieved from [Link]

UNDP. (2018). BIOFIN Workbook 2018: Finance for Nature. The Biodiversity Finance Initiative. United Nations Development Programme: New York. Retrieved from [Link]

UNDP. (2020). Financing Solutions for Sustainable Development. Retrieved from [Link] 
Yu., Serpeninova, I., Makarenko, A., Plastun, A., Babko, G. Gasimova. Mapping of the Responsible Investments Instruments in SDG 3 «Good Health and Well-Being» Financing: EU and US experience

WBG. (2018). World Bank benchmark Canadian dollar bond highlights benefits of investing in women and young people. Retrieved from [Link]

WBG. (2020a). World Bank starts its 2020 benchmark program with cad 15 billion sustainable development bond while raising awareness for the critical role of fresh and saltwater resources. Retrieved from [Link]

WBG. (2020b). World bank bonds for sustainable development. Retrieved from [Link]

WBG. (2020c). World Bank Group Launches First Operations for COVID-19 (Coronavirus) Emergency Health Support, Strengthening Developing Country Responses. Retrieved from [Link]

World Health Organization. (2004). Tax-based financing for health systems: options and experiences. Retrieved from [Link]

Ю. С. Серпенінова, к.е.н., доцент, Сумський державний університет (Україна);

І. О. Макаренко, д.е.н., доцент, Сумський державний університет (Україна);

О. Л. Пластун, д.е.н., професор, Сумський державний університет (Україна);

А. М. Бабко, Наиіональна служба здоров'я, (Україна);

Г. Гасимова, викладач, Університет Хазар (Азербайджан)

Картування інструментів відповідального інвестування для фінансування SDG 3 «Міцне здоров'я та благополуччя»: досвід Європейського Союзу та США

Стаття узагальнює наукові підходи щодо дослідження інструментів відповідального інвестування у ссрері охорони здоров'я з урахуванням досвіду Європейського Союзу та США. Основною метою дослідження є ідентисрікація інструментів відповідального інвестування у сффері фінансового забезпечення Цілі сталого розвитку 3 «Міцне здоров'я та добробут». Систематизаиія джерел та підходів до виокремлення фінансових інструментів провідними світовими установами та організаціями засвідчила відсутність єдиного підходу до формування переліку інструментів відповідального інвестування при фінансуванні витрат на охорону здоров'я та добробут. Так, наявні підходи відрізняються за параметрами ризику, дохідності, придатності для фінансування тощо. Таким чином, актуальність розв'язання наукової проблеми полягає в аналізі, узагальненні та дослідженні практичних аспектів реалізації наявних підходів. Автори відмітили, що такі організації як Фінансова ініціатива біорозмаїття у рамках ПРООН, Агентство США з міжнародного розвитку та Світовий банк здійснили найбільший вклад у фінансування проєктів у сфрері охорони здоров'я. Таким чином, об'єктом дослідження обрано підходи до фінансування охорони здоров'я в зазначених вище організаціях. Для досягнення поставленої мети, дослідження здійснено в такій логічній послідовності: 1) охарактеризовано фінансові рішення Біофріну у рамках ПРООН у сфері охорони здоров'я; 2) систематизовано підходи Агентства США з міжнародного розвитку у сфрері фінансування прогресу досягнення Цілі зі сталого розвитку «Міине здоров'я та добробут»; 3) узагальнено практичні напрямки реалізації зазначених інструментів з поглибленим аналізом діяльності Світового банку у ссрері відповідального інвестування у галузі охорони здоров'я. Методичним інструментарієм дослідження є метод типологій, спрямований на ідентифікацію ключових критеріїв класифікації інструментів відповідального інвестування, та метод картування, спрямований на узагальнення наукових напрацювань у сфері фінансового забезпечення охорони здоров'я. Результати проведеного дослідження можуть бути корисними для науковців при проведенні подальших досліджень щодо розвитку та уніфікації класифікації інструментів відповідального інвестування у сффері сталого розвитку та фінансування охорони здоров'я. За результатами дослідження автори визначили практичні напрямки використання наявних світових підходів для удосконалення фінансування національної системи охорони здоров'я та досягнення встановлених таргетів Цілі сталого розвитку «Міине здоров'я та добробут».

Ключові слова: охорона здоров'я, фінансування, інвестування, облігації, сталий розвиток.

Manuscript received: 23.06 .2020

(c) The author(s) 2020. This article is published with open access at Sumy State University. 